\title{
Lay beliefs on Polish oncology in the evaluation of healthy individuals
}

\author{
Małgorzata Synowiec-Piłat ${ }^{1}$ \\ 1 Zakład Humanistycznych Nauk Lekarskich, Uniwersytet Medyczny im. Piastów Śląskich we Wrocławiu, Poland
}

Synowiec-Piłat M, Lay beliefs on Polish oncology in the evaluation of healthy individuals. Ann Agrice Environ Med. $2017 ; 24(4)$ : 648-653. doi: $10.5604 / 12321966.1232087$

\section{Abstract}

Introduction. Poland is among the countries which reported the highest rates of mortality from cancer. The health behaviours of people are influenced, among other things, by their beliefs about cancer, but their evaluation of oncological institutions and specialists seems also to be of great importance.

Objectives. 1. How the respondents evaluate Polish oncology: a) the conditions of treatment in oncology hospitals, b) access to oncological medical services, c) the competence of oncologists. 2. What are the socio-cultural factors of the assessment of Polish oncology? 3. What is the influence of the grade level of the assessment of Polish oncology on the degree of fear and the knowledge about cancer?

Materials and method. The study was carried out with a sample of 910 adult residents of Wroclaw in south-west Poland. Quota sampling was used. An interview questionnaire was used as the method.

Results. Analysis of the data showed a negative image of Polish oncology, according to the study participants: dissatisfaction with both treatment conditions and with access to medical services. Assessment of Polish oncology depends primarily on education, age and economic situation, as well as 'family history of cancer', and attitude towards doctors. The lower the rating of Polish oncology, the lower the medical knowledge, and the higher the level of fear of cancer.

Conclusions. Negative assessment of Polish oncology perpetuates the fear of cancer in society. There is a need for constant improvement of the quality of medical oncology services, for building public trust in physicians, to fight inequalities in health, and to take into account the lay perspectives in developing strategies to combat cancer.

\section{Key words}

sociology of health and illness, lay perspective, medical institutions, oncology, cancer, lay referral system, medical knowledge, fear of cancer

\section{INTRODUCTION}

Cancer is now the second cause, after cardiovascular diseases, of morbidity and mortality in Europe [1]. Poland is among the countries which reported the highest rates of mortality from cancer [2]. In the prevention of cancer, particularly important are: prophylaxis, an early diagnosis, and starting prompt and effective therapy. The use of medical services is dependent on the type of symptoms experienced, on psychological and socio-cultural characteristics, as well as on the immediate environment of the individual. As E. Freidson noted, the concept lay referral system [3], health and illness, the etiology of the disease, its treatments, diagnostics etc., are interpreted by layperson criteria, rather than scientific standards. This, in turn, has an impact on the attitudes and health behaviours of people. Lay referral system is composed of non-professionals - family members, friends, neighbours - who assist in the interpretation of the individual's symptoms and in the choice of the action taken $[4,5]$. Seeking the advice of a professional is usually the last step - after self-treatment and self-care - in the process of looking for help [6], also in the case of cancer [7]. As part of the lay referral system, help is granted to an individual, but it is also a subject of social control. The lay system can exert pressure on the sick individual to notify the physician, to undergo diagnostic tests, and to comply with medical recommendations. But it may also discourage or even prohibit the sick individual from contacting medical professionals [4].

Address for correspondence: Małgorzata Synowiec-Piłat

E-mail:m.synowiecpilat@gmail.com

Received: 22 April 2014; accepted: 29 october 2014; first published on February 2017
In the case of cancer, particular attention should be paid to issues prevailing in the society such as 'fear of cancer' $[7,8]$, fatalistic beliefs $[9,10]$ or stigma accompanying cancer $[7,11$, and 12]. Functioning in a culture of a given group an individual assimilates certain ideals and beliefs about cancer. As noted by S. Sontag, due to the low cure rate and the accompanying suffering, cancer appears in the public consciousness as a mysterious and sinister disease, experienced as a cruel, covert invasion of the human body. The very word 'cancer' bears the seal of judgment. This disease is identified with a painful death, and often described as a process in which the body is consumed. There is a widespread belief that cancer is not subject to any control, is incurable and the treatment is worse than the disease [13]. Dominance of the belief in the social environment of the individual that cancer is an incurable and rapidly fatal disease promotes passivity and improper health behaviorus. People's health behaviours are influenced not only by their beliefs about cancer, but also by their assessment of oncology centres and specialists. The conviction of the dysfunctionality of medical institutions can deepen fatalistic beliefs about not only the efficacy of the treatment, but also the rationality of taking any action for health. Therefore, particularly important seems to be the examination of the attitudes and beliefs of laymen on the issue of cancer and their evaluation of Polish oncology. For it is laymen, functioning in specific communities, who make decisions regarding their own health and they also influence the health decisions of others.

Considering the lay perspective in the studies regarding the problem of cancer seems to be even more important, since the activities to fight cancer conducted so far (i.e. health 
programmes and social campaigns) have not produced satisfactory results in the form of a positive change in the attitudes and health behaviors and in the reduction of morbidity and mortality rates. An in-depth study of ordinary people's beliefs regarding cancer issues and the impact of those beliefs on the behaviour and attitudes toward health is seen as a promising way to develop effective strategies to fight cancer.

There is a rich scientific literature documenting the existence of fatalistic beliefs about cancer in Western Europe [14, 15, and 16] and United States [17]. Limited studies concerning this subject were carried out in Poland, where psychological studies dominate and focus primarily on the issues of the fear of cancer and cancer's consequences [18]. Very rarely the main subjects of those studies are people's beliefs about cancer [19]. One of the few examples of such studies was conducted in the 1990s concerning colorectal cancer [7]. There is a lack of sociological research on contemporary beliefs about cancer. Sociological studies which would present the contemporary beliefs about cancer are missing. The conducted studies mostly included sick patients [10], whereas research that examined healthy individuals usually concentrated on a small research sample [20]. Additionally, the existing research on beliefs about cancer most often focus on their dependence on SES $[21,22]$ and the impact of those beliefs on the preventive behaviour of individuals [23, 24]. Missing are analyses regarding the socio-cultural conditions and the consequences of the way laymen evaluate medical oncology institutions.

\section{OBJECTIVES}

The aim of this study was to answer the following research questions:

1. How the respondents evaluate Polish oncology in the following dimensions:

a) conditions of medical care in oncological hospitals;

b) access to treatment in an oncological hospital, oncologists, oncological clinics, cancer prevention examination, and rehabilitation after oncological treatment;

c) competencies (knowledge, experience) of oncologists;

d)care functions implemented by medical personnel (providing emotional support for patients).

2. What are the socio-cultural factors of the assessment of Polish oncology?

3. What is the influence of the level of assessment of Polish oncology on the degree of fear and knowledge about cancer?

\section{MATERIALS AND METHOD}

The study was carried out between March - June in 2012 with a sample of 910 adult residents of Wroclaw in south-east Poland. The quota sample which reflected the structure of the study population in terms of gender, age and education was used in the research. The study was based on an interview questionnaire. The chi-square test of independence was used to verify the hypothesis about the independence of pair of nominal variables. The strength of dependence was evaluated by the Cramer's V coefficient. The values of $\mathrm{V}$ were at the level of $0.1-0.3$ which, in the case of random sampling, ensures a significant dependence ( $\mathrm{p}$-value $<0.05)$.
The correspondence analysis was used to determine the direction of the dependence between nominal and ordinal variables. The values of chi-square test statistic and Cramer's $\mathrm{V}$ coefficient are presented in Tables 3 and 4. Data were analyzed using the Statistica 9.0 version.

To assess the access to oncology medical services, competence of the oncologists, medical care conditions, degree of confidence in doctors and degree of fear of cancer, a 4 element version of the Likert's scale (i.e. forced choice scale) was used. In questions relating the medical knowledge, respondents were asked 4 independent questions: do they know the symptoms of cancer, risk factors, types of cancer prevention examination, andmethods of cancer treatment? If so, they were supposed to list them. Responses were classified according to the following formula: lack of response, 1. -2 . -3 . and above 3 correct answers.

\section{RESULTS}

1. Assessment of Polish oncology by healthy respondents. Less than half of the respondents (48\%) assesd the conditions of medical care in Polish oncology hospitals as satisfactory. The highest rated were the competencies of oncologists, since only $21 \%$ of respondents believed that they are low. However, the interpersonal skills of the specialists were poorly rated: only $57 \%$ were convinced that while in hospital cancer patients can count on emotional support from medical staff (Tab.1).

Table 1. Rating of Polish oncology by healthy respondents $(N=910)$

\begin{tabular}{|c|c|c|c|c|c|c|c|c|}
\hline \multirow{2}{*}{ HOW WOULD YOU RATE: } & \multicolumn{2}{|c|}{ excellent } & \multicolumn{2}{|c|}{ rather good } & \multicolumn{2}{|c|}{ rather bad } & \multicolumn{2}{|c|}{ very bad } \\
\hline & $\mathrm{n}$ & $\%$ & $\mathrm{n}$ & $\%$ & $\mathrm{n}$ & $\%$ & $\mathrm{n}$ & $\%$ \\
\hline \multirow[t]{3}{*}{$\begin{array}{l}\text { medical care conditions } \\
\text { in most Polish oncology } \\
\text { hospitals }\end{array}$} & 13 & 2 & 418 & 46 & 367 & 40 & 112 & 12 \\
\hline & \multicolumn{2}{|c|}{ very high } & \multicolumn{2}{|c|}{ rather high } & \multicolumn{2}{|c|}{ rather low } & \multicolumn{2}{|c|}{$\begin{array}{c}\text { definitely } \\
\text { low }\end{array}$} \\
\hline & $\mathrm{n}$ & $\%$ & $\mathrm{n}$ & $\%$ & $\mathrm{n}$ & $\%$ & $\mathrm{n}$ & $\%$ \\
\hline $\begin{array}{l}\text { competencies } \\
\text { (knowledge, experience) } \\
\text { of the majority of } \\
\text { oncologists in our country }\end{array}$ & 68 & 8 & 648 & 71 & 148 & 16 & 46 & 5 \\
\hline $\begin{array}{l}\text { interpersonal skills of } \\
\text { medical staff (providing } \\
\text { emotional support for } \\
\text { oncological patients } \\
\text { staying in hospital) }\end{array}$ & 54 & 6 & 460 & 51 & 319 & 8 & 77 & 35 \\
\hline
\end{tabular}

Respondents were also asked how they assessed access to oncological medical services (Tab. 2). Most respondents believed that access to oncological hospital treatment (62\%) and cancer prevention examination (59\%) in Poland is unsatisfactory. An even worse assessment concerned access to oncologists, oncological clinics (just under 32\% stated it is satisfactory), and the worst of all - to rehabilitation after cancer treatment (76\% of respondents believed that it is unsatisfactory).

2. The influence of the socio-economic factors on the assessment of Polish oncology. Assessment of the Polish oncology in the above dimensions is conditioned by socio- 
Table 2. Rating of access to oncology medical services $(\mathrm{N}=910)$

\begin{tabular}{|c|c|c|c|c|c|c|c|c|}
\hline \multirow{2}{*}{$\begin{array}{l}\text { What in your opinion is } \\
\text { access in our country to: }\end{array}$} & \multicolumn{2}{|c|}{ excellent } & \multicolumn{2}{|c|}{$\begin{array}{l}\text { rather } \\
\text { good }\end{array}$} & \multicolumn{2}{|c|}{ rather poor } & \multicolumn{2}{|c|}{ very poor } \\
\hline & $n$ & $\%$ & $\mathrm{n}$ & $\%$ & $n$ & $\%$ & $n$ & $\%$ \\
\hline $\begin{array}{l}\text { cancer prevention } \\
\text { examination }\end{array}$ & 19 & 2 & 353 & 39 & 390 & 43 & 148 & 16 \\
\hline $\begin{array}{l}\text { oncologists, oncological } \\
\text { clinics }\end{array}$ & 17 & 2 & 278 & 30 & 445 & 49 & 170 & 19 \\
\hline $\begin{array}{l}\text { oncological hospital } \\
\text { treatment }\end{array}$ & 16 & 2 & 327 & 36 & 412 & 45 & 155 & 17 \\
\hline $\begin{array}{l}\text { rehabilitation after } \\
\text { oncological treatment }\end{array}$ & 14 & 1 & 208 & 23 & 445 & 49 & 243 & 27 \\
\hline
\end{tabular}

Source: own research

economic factors, in particular, by the following variables: education, age and economic situation of the respondents (Tab. 3).

It was confirmed that the assessment of the competence of oncologists is dependent on education $(p=0.03628)$ : the lowest educated persons (primary and vocational education), often assess these competencies as definitely low, while respondents with secondary education perceived competence of oncologists as rather high. There was no clear relationship between the variable of the assessment of competence and higher education.

Another variable that affects the assessment of Polish oncology is the age of the respondents. Firstly, the increase in age of the respondents increased the critical evaluation of the conditions of the oncological medical care in hospitals ( $p=0.101128)$. Secondly, older people often evaluated access to rehabilitation as very weak, while younger respondents as being rather weak (18-24 years) and rather good (2534 years old) $(p=0.00011)$. However, there was no clear correlation between any category of assessment of access to rehabilitation and the age categories 35-44, and 65 years and over.

Special attention should be paid to the economic situation of the respondents, both in objective (the amount of income per member of the family) and subjective (evaluation of the economic situation) terms. It was confirmed that the lower the income of respondents, the worse the evaluation of the following: the conditions of medical care $(p=0.00234)$, competence of oncologists $(p=0.00001)$, and the possibility of receiving emotional support from medical personnel by cancer patients $(p=0.00056)$. The same direction of the correlation was confirmed in the case of the subjective evaluation of the economic situation: the worse the evaluation of their own economic situation, the lower the evaluation of medical care $(p=0.00097)$, competence of the oncologists $(p=0.00003)$, possibility of receiving emotional support from medical personnel by patients $(p=0.00019)$; access to: hospital treatment $(p=0.00044)$, oncologists, oncology clinics $(p=0.04292)$ and rehabilitation $(p=0.04482)$.

The assessment of Polish oncology was also significantly influenced by:

a) The education level of the respondent's mother and father, which was related to the process of socialization, and shaping of health behaviorus and attitudes, including attitudes towards medicine, by the parents. The education of people who influence our process of socialization had the biggest impact and it was not irrelevant. It has been confirmed that the lower the education of the mother

Table 3. Socio-cultural factors influencing assessment of Polish oncology

\begin{tabular}{|c|c|c|c|c|c|c|c|}
\hline & \multirow{2}{*}{$\begin{array}{l}\text { Evaluation of } \\
\text { medical care } \\
\text { conditions }\end{array}$} & \multicolumn{4}{|c|}{ PERCEPTION OF ACCESS TO } & \multirow{2}{*}{$\begin{array}{l}\text { Perception of } \\
\text { competence of } \\
\text { oncologists }\end{array}$} & \multirow{2}{*}{$\begin{array}{l}\text { Perception of } \\
\text { possibility to } \\
\text { receive support } \\
\text { from medical staf }\end{array}$} \\
\hline & & $\begin{array}{l}\text { Oncological } \\
\text { hospital } \\
\text { treatment }\end{array}$ & $\begin{array}{l}\text { Oncologists, } \\
\text { oncological } \\
\text { clinics }\end{array}$ & $\begin{array}{c}\text { Cancer } \\
\text { prevention } \\
\text { examination }\end{array}$ & $\begin{array}{l}\text { Rehabilitation } \\
\text { after oncological } \\
\text { treatment }\end{array}$ & & \\
\hline Education & ns & ns & ns & ns & ns & $\begin{array}{c}\mathrm{Chi}^{2}=17.90731 \\
\mathrm{~V}=0.0809904\end{array}$ & ns \\
\hline Age & $\begin{array}{l}\mathrm{Chi}^{2}=30.18479 \\
\mathrm{~V}=0.1051508\end{array}$ & ns & ns & ns & $\begin{array}{l}\mathrm{Chi}^{2}=44.09736 \\
\mathrm{~V}=0.1270940\end{array}$ & ns & ns \\
\hline $\begin{array}{l}\text { evaluation of economic } \\
\text { situation }\end{array}$ & $\begin{array}{l}\mathrm{Chi}^{2}=22.54187 \\
\mathrm{~V}=0.1112908\end{array}$ & $\begin{array}{l}\mathrm{Chi}^{2}=24.39768 \\
\mathrm{~V}=0.1157813\end{array}$ & $\begin{array}{l}\mathrm{Chi}^{2}=13.00759 \\
\mathrm{~V}=0.0845401\end{array}$ & ns & $\begin{array}{l}\mathrm{Chi}^{2}=12.89036 \\
\mathrm{~V}=0.0841583\end{array}$ & $\begin{array}{l}\mathrm{Chi}^{2}=30.48599 \\
\mathrm{~V}=0.1294239\end{array}$ & $\begin{array}{l}\mathrm{Chi}^{2}=30.48599 \\
\mathrm{~V}=0.1204817\end{array}$ \\
\hline Income & $\begin{array}{l}\mathrm{Chi}^{2}=30.51140 \\
\mathrm{~V}=0.1057182\end{array}$ & ns & ns & ns & ns & $\begin{array}{l}\mathrm{Chi}^{2}=44.21796 \\
\mathrm{~V}=0.1272677\end{array}$ & $\begin{array}{l}\mathrm{Chi}^{2}=34.49601 \\
\mathrm{~V}=0.1124095\end{array}$ \\
\hline mother's education & ns & $\begin{array}{l}\mathrm{Chi}^{2}=25.45285 \\
\mathrm{~V}=0.0965577\end{array}$ & ns & $\begin{array}{l}\mathrm{Chi}^{2}=25.55086 \\
\mathrm{~V}=0.0967434\end{array}$ & ns & $\begin{array}{l}\mathrm{Chi}^{2}=21.30604 \\
\mathrm{~V}=0.0883426\end{array}$ & ns \\
\hline father's education & ns & $\begin{array}{l}\mathrm{Chi}^{2}=24.29922 \\
\mathrm{~V}=0.0943441\end{array}$ & ns & $\begin{array}{l}\mathrm{Chi}^{2}=22.39994 \\
\mathrm{~V}=0.0905820\end{array}$ & ns & $\begin{array}{l}\mathrm{Chi}^{2}=20.87339 \\
\mathrm{~V}=0.0874410\end{array}$ & ns \\
\hline $\begin{array}{l}\text { suffering from chronic } \\
\text { diseases }\end{array}$ & ns & ns & ns & $\begin{array}{l}\mathrm{Chi}^{2}=8.122793 \\
\mathrm{~V}=0.0944783\end{array}$ & ns & ns & ns \\
\hline $\begin{array}{l}\text { occurrence of cancer in the } \\
\text { immediate family }\end{array}$ & ns & ns & $\begin{array}{l}\mathrm{Chi}^{2}=12.99161 \\
\mathrm{~V}=0.0844882\end{array}$ & $\begin{array}{l}C^{2}{ }^{2}=12.76656 \\
V=0.0837532\end{array}$ & ns & ns & ns \\
\hline $\begin{array}{l}\text { care for someone with } \\
\text { cancer }\end{array}$ & ns & ns & ns & $\begin{array}{l}\mathrm{Chi}^{2}=15.42221 \\
\mathrm{~V}=0.0920529\end{array}$ & ns & ns & ns \\
\hline $\begin{array}{l}\text { perception of competence } \\
\text { of oncologists, }\end{array}$ & $\begin{array}{l}\mathrm{Chi}^{2}=365.9907 \\
\mathrm{~V}=0.3661455\end{array}$ & $\begin{array}{c}\mathrm{Chi}^{2} \mathrm{a}=165.2292 \\
\mathrm{~V}=0.2460153\end{array}$ & $\begin{array}{l}C h i^{2} a=142.657 \\
V=0.2285944\end{array}$ & $\begin{array}{l}\mathrm{Chi}^{2}=129.9361 \\
\mathrm{~V}=0.2181642\end{array}$ & $\begin{array}{l}\mathrm{Chi}^{2}=95.60497 \\
\mathrm{~V}=0.1871367\end{array}$ & - & $\begin{array}{l}\mathrm{Chi}^{2}=317.4088 \\
\mathrm{~V}=0.3409794\end{array}$ \\
\hline $\begin{array}{l}\text { degree of confidence in } \\
\text { doctors }\end{array}$ & $\begin{array}{l}\mathrm{Chi}^{2}=194.8071 \\
V=0.2671290\end{array}$ & $\begin{array}{l}C h i^{2}=69.29257 \\
V=0.1593170\end{array}$ & $\begin{array}{c}\mathrm{Chi}^{2}=66.97997 \\
\mathrm{~V}=0.1566358\end{array}$ & $\begin{array}{c}\mathrm{Chi}^{2}=82.26628 \\
\mathrm{~V}=0.1735920\end{array}$ & $\begin{array}{c}\mathrm{Chi}^{2}=76.97012 \\
\mathrm{~V}=0.1679112\end{array}$ & $\begin{array}{l}\mathrm{Chi}^{2}=366.0984 \\
\mathrm{~V}=0.3661993\end{array}$ & $\begin{array}{l}\mathrm{Chi}^{2}=315.8063 \\
\mathrm{~V}=0.3401176\end{array}$ \\
\hline
\end{tabular}

$\mathrm{Chi}^{2}$ (Pearson's chi-squared statistic); V-Cramer (Cramér's V); ns - not significant correlation

Source: own research 
and father of the respondent, the worse the rating of the competence of oncologists $(p=0.01136 ; p=0.01323)$, access to hospital treatment $(p=0.00251 ; p=0.00386)$, and access to prevention ( $p=0.00242 ; p=0.00770)$.

b) The so-called 'family history of cancer'. Firstly, it was confirmed that access to prevention was rated the worst by persons suffering from chronic diseases $(p=0.04355)$, by respondents who had a close family where there were cases of cancer $(p=0.04691)$, and by respondents who took care of a sick person with cancer $(p=0.01722)$. Secondly, the respondents whose relatives suffered from cancer often assessed access to oncologists and oncological clinic as rather weak and very weak. In contrast, respondents where nobody in the family was sick with cancer considered them to be rather good and rather weak $(p=0.04318)$.

c) Attitude towards doctors. Two variables were taken into account: the perception of competence of oncologists and the degree of confidence in doctors overall. The perception of competence of oncologists affects all the indicators taken into account when assessing the Polish oncology. It was confirmed that the higher the assessment of competence of oncologists, the better the rating of the conditions of medical care $(p=0.0000)$, possibility of obtaining emotional support from medical staff by patients $(p=0.0000)$, access to hospital treatment $(p=0.0000)$, oncologists, oncological clinics $(p=0.0000)$, prevention $(p=0.0000)$ and rehabilitation $(p=0.00000)$. Also, the degree of confidence in doctors affected all indicators of assessment of Polish oncology. It was confirmed that the higher the confidence in doctors, the better the rating of conditions of medical care $(p=0.0000)$, competence of oncologists $(p=0.0000)$, possibility of obtaining emotional support from medical personnel by patients, access to hospital treatment $(p=0.00000)$, oncologists, oncological clinics $(p=0.00000)$; prevention $(p=0.00000)$ and rehabilitation $(p=0.00000)$.

3. The influence of the assessment of Polish oncology on the degree of fear and the medical knowledge about cancerrelated issues. The level of medical knowledge related to oncology issues is affected by the following variables: assessment of competence of oncologists, assessment of the medical care in oncology hospitals, and assessment of access to cancer prevention examination (Tab. 4).
Firstly, the worse the assessment of competence of oncologists, the lower the level of respondents' knowledge about the symptoms of cancer $(p=0.00027)$, risk factors $(p=0.00000)$; preventive testing $(p=0.00000)$ and treatment of cancer $(p=0.00000)$. Secondly, the worse the evaluation of access to cancer prevention examination, the poorer the knowledge of symptoms $(p=0.00271)$ and cancer risk factors $(p=0.03453)$. Thirdly, the worse the assessment of the medical care in oncology hospitals, the less the knowledge about: symptoms of cancer $(p=0.00150)$, and the risk factors $(p=0.00012)$ and treatment methods $(p=0.02594)$.

In the literature concerning cancer issues the problem of the existence of the fear of cancer phenomena is often raised. Therefore, in the interview questionnaire, respondents were asked if they feel anxious when thinking about cancer. The great majority of respondents (80\%) experienced anxiety, although with varying levels of intensity: $10 \%$ - very high, $33 \%$-to a big extent, and $37 \%$ - to a lesser extent. Only $20 \%$ of respondents said they did not feel anxiety when thinking about cancer. Particularly noteworthy is the fact that the level of fear of cancer affects how Polish oncology is evaluated. The level of fear of cancer is higher when worse is the assessment of the conditions of medical care in hospitals ( $\mathrm{p}=0.04291$ ), and evaluation of access to preventive testing $(\mathrm{p}=0.02919)$ (Tab. 4$)$.

\section{DISCUSSION}

Analysis of the data showed a negative image of Polish oncology, according to the study participants. The respondents were dissatisfied with both the treatment conditions, and with access to medical services. Almost half of the respondents (48\%) did not believe in the efficacy of modern medicine in the fight against cancer. Instrumental competences of oncologists were assessed relatively highly (79\%). The interpersonal skills of medical personnel and their emotional support were much more critically perceived.

There are a number of variables affecting the assessment of Polish oncology. Particular attention should be paid to the issue of inequality in health and disease. Low-income respondents poorly evaluated the quality of oncology medical services (treatment conditions in hospitals, doctors and their competence, and interpersonal skills) and access

Table 4. Influence of the assessment of Polish oncology on the degree of fear of cancer and medical knowledge of respondents

\begin{tabular}{|c|c|c|c|c|c|c|}
\hline \multirow{2}{*}{$\begin{array}{l}\text { Medical } \\
\text { knowledge } \\
\text { concerning: }\end{array}$} & \multirow{2}{*}{$\begin{array}{l}\text { Evaluation of medical } \\
\text { care conditions }\end{array}$} & \multicolumn{3}{|c|}{ Perception of access to: } & \multirow{2}{*}{$\begin{array}{l}\text { Perception of } \\
\text { competence of } \\
\text { oncologists }\end{array}$} & \multirow{2}{*}{$\begin{array}{l}\text { Perception of the possibility } \\
\text { to receive emotional } \\
\text { support from medical staff }\end{array}$} \\
\hline & & $\begin{array}{l}\text { Oncological hospital } \\
\text { treatment }\end{array}$ & $\begin{array}{c}\text { Oncologists, } \\
\text { oncological clinics }\end{array}$ & $\begin{array}{l}\text { Cancer prevention } \\
\text { examination }\end{array}$ & & \\
\hline cancer symptoms & $\begin{array}{c}\mathrm{Chi}^{2}=31.76809 \\
\mathrm{~V}=0.1078734\end{array}$ & ns & ns & $\begin{array}{c}C^{C h i}{ }^{2}=30.09372 \\
V=0.1049921\end{array}$ & $\begin{array}{c}\mathrm{Chi}^{2}=36.54493 \\
\mathrm{~V}=0.1156997\end{array}$ & ns \\
\hline $\begin{array}{l}\text { risk factors } \\
\text { for cancer }\end{array}$ & $\begin{array}{c}\mathrm{Chi}^{2}=38.57493 \\
\mathrm{~V}=0.1188697\end{array}$ & ns & ns & $\begin{array}{c}\mathrm{Chi}^{2}=22.27832 \\
\mathrm{~V}=0.0903358\end{array}$ & $\begin{array}{l}\mathrm{Chi}^{2}=57.59018 \\
\mathrm{~V}=0.1452422\end{array}$ & ns \\
\hline $\begin{array}{l}\text { cancer prevention } \\
\text { examination }\end{array}$ & ns & ns & ns & ns & $\begin{array}{l}\mathrm{Chi}^{2}=47.13677 \\
\mathrm{~V}=0.2275932\end{array}$ & ns \\
\hline $\begin{array}{l}\text { Degree of fear of } \\
\text { cancer }\end{array}$ & $\begin{array}{l}\mathrm{Chi}^{2}=17.39329 \\
V=0.0798196\end{array}$ & ns & ns & $\begin{array}{c}\mathrm{Chi}^{2}=18.56253 \\
V=0.0824588\end{array}$ & ns & ns \\
\hline
\end{tabular}


to hospital treatment, oncologists and oncological clinics and rehabilitation. Numerous studies have confirmed that access to specialist medical services in Poland, in the case of low-income persons, is difficult [25], and it may perpetuate passivity in seeking medical help. In addition, fatalistic beliefs about cancer are more prevalent among those with lower SES $[15,17,21,22]$.

The individual pattern of behaviour when healthy and ill depends largely on the immediate environment of the individual. The primary socialization with the particular role of parents is of undeniable importance. It has been confirmed that the lower the education of the parents of the respondent, the worse the rating of the competence of oncologists, assessment of the access to hospital treatment, and access to prevention. In the process of socialization of people in the lower social class, an unfavourable image of Polish oncology is being formed, which may lead to taking on or the continuation of inappropriate health behaviours and passivity toward the health care services.

The choice of a behavioural strategy in health and illness behaviour; whether an individual will establish contact with medicine, depends on the diagnosis that one gives on the basis of his or her knowledge, and depends on social status. Knowledge of the individual is enriched by the experiences of illness, family members' experience (i.e. family history of the disease), and those in the immediate and distant environment. 'Family history of cancer' promotes fatalistic beliefs [9] and, consequently, can act as a barrier to undertaking effective measures to promote health [16]. In the presented study, previous experience of chronic disease and the occurrence of cancer in the immediate family, increased the negative perception of Polish oncology (access to prevention and to oncologists, oncological clinics), which can be explained by adverse experiences in dealing with the health care services.

The respondents' attitude toward doctors also had a significant influence on the perception of Polish oncology, namely, their assessment of oncologists' competence and their general confidence level in doctors. It was confirmed that the lower the confidence in the doctors and the lower the assessment of the competence of oncologists, the worse the evaluation of both treatment conditions in hospitals, and access to medical oncology services. In addition, the variable of the assessment of the competence of oncologists affected both the medical knowledge of the respondents and the majority of analyzed beliefs related to cancer. Therefore, the need to build a positive image of oncologists is proposed, with an emphasis on caring and emotional support which, in the eyes of cancer patients and their loved ones, is especially important.

How we evaluate Polish oncology influences the knowledge about cancer. It was confirmed that the worse the assessment of the conditions of medical care, competence of oncologists, and access to preventive examinations, the lower the medical knowledge of the respondents about the cancer. The scope of information associated with the disease which man possesses is undoubtedly (next to the attitudes and skills) an important determinant of our behaviour in health and in illness. In contrast, the negative perception of health care is not conducive to a deepening of knowledge on the subjects of oncology, it can even be demotivating.

Due to the existence of the fear of cancer phenomenon, the level of fear of cancer in healthy subjects deserves special attention. High levels of fear can result in a delay in reporting to a doctor [10]. In addition, when the individual observes alarming symptoms and begins to interpret them as cancer symptoms, it usually triggers the fear of pain and suffering, fear of a very invasive and incriminating treatment (surgical operation, chemotherapy), and hospitalization itself. Concerns may indeed also be raised by the health care system, perceived lack of access to medical services and the professionalism of the medical staff. The issue of trust in the professional medical health care system should be addressed. A low level of trust in medicine, or lack of it, reduces the likelihood of a quick contact with specialists if one notices symptoms of the illness [26].

The presented study has confirmed that the great majority of respondents $(80 \%)$ experienced anxiety when thinking about cancer and when the level of that fear was higher, the worse they assessed the conditions of medical care in hospitals and access to preventive testing.

\section{CONCLUSIONS}

Negative assessment of Polish oncology deepens with the fear of cancer and promotes the preservation of fear of cancer in the society. There is a need for constant improvement in the quality of medical oncology services and building public trust in physicians, fighting inequalities in health, and the taking into account of the layman's perspective in developing strategies to fight cancer.

\section{REFERENCES}

1. Boyle P, Levin B. World Cancer Report 2008. Lyon, WHO International Agency for Research on Cancer, 2008.

2. European Commission EUROSTAT. 2009 http://epp.eurostat. ec.europa.eu/statistics_explained/images/4/4e/Causes_of_death_-_ standardised_death_rate\%2C_2009_(1)_(per_100_000_inhabitants_ aged_less_than_65).png (access: 2013.10.29).

3. Freidson E. Profession of medicine: a study of the sociology of applied knowledge. Chicago, University of Chicago Press, 1970.

4. Coockerham WC. Medical sociology. New Jersey, Pearson Prentice Hall, 2007.

5. Freidson E. Client Control and Medical Practice. American J of Sociology. 1960; 65: 374-82.

6. Cornford CS, Cornford HM. „I'm only here because of my family”. A study of lay referral network. British Journal of General Practice. 1999; 49: 617-620.

7. Tobiasz-Adamczyk B, Szafraniec K, Bajka J. Zachowania w chorobie. Opis przebiegu choroby z perspektywy pacjenta. Kraków, Collegium Medicum UJ, 1999.

8. Jokiel M. Opinia społeczna o chorobach nowotworowych. Warszawa, OBOP SP, 1990.

9. Lykins ELB, Graue LO, Brechting EH, Roach AR, Gochett CG, Andrykowski MA. Beliefs about cancer causation and prevention as a function of personal and family history of cancer: a national, population-based study. Psycho-Oncology. 2008; 17: 967-974.

10. Chojnacka-Szawłowska G, Kościelak R, Karasiewicz K, Majkowicz M, Kozaka J. Delays in seeking cancer diagnosis in relations to beliefs about the curability of cancer in patients with different disease locations. Psychol Health. 2013; 28(2): 154-70.

11. Bloom J, Kessler L. Emotional support following cancer: a test of the stigma and social activity hypotheses. J. of Health and Social Behavior. 1994; 35: 118-133.

12. Chapple A et al. Stigma, shame, and blame experienced by patients with lung cancer: qualitative study. Br. Med. J. 2004; 328: 1470-1474.

13. Sontag S. Choroba jako metafora. AIDS i jego metafory. Warszawa, PIW, 1994.

14. Beeken RJ, Simon AE AE, von Wagner C, Whitaker KL, Wardle J. Cancer fatalism: deterring early presentation and increasing social inequalities?. Cancer Epidemiol Biomarkers Prev. 2011; 20(10): 2127-2131. 
15. Mayo RM, Ureda JR, Parker VG. Importance of fatalism in understanding mammography screening in rural elderly women. J Women Aging. 2001; 13: 57-72.

16. Davison C, Frankel S, Smith GD. The limits of lifestyle: re-assessing "fatalism" in the popular culture of illness prevention. Soc Sci Med. 1992; 34: 675-85.

17. Powe BD. Cancer fatalism among elderly African American women predictors of the intensity of the perceptions. J Psychosoc Oncol. 2001; 19: 85-95.

18. Chojnacka-Szawłowska G, Stres a rak. Psychologia i medycyna wspólne obszary zainteresowań. Warszawa, Seria Psychologia, 1, 2007

19. Chojnacka-Szawłowska G. Opinions about cancer and health- related behaviour in the Polish socjety. In: Maliszewski T, Wojtowicz WJ, Żerko J (eds.). Anthology of Social and Behavioural Sciences. Linkoping, Linkoping University, 2005. p. 393-401.

20. Chojnacka-Szawłowska G. Poczucie zagrożenia chorobą nowotworową przez palących i niepalących. In: Chojnacka-Szawłowska G, PastwaWojciechowska B. (eds.). Kliniczne i sądowo - penitencjarne aspekty funkcjonowania człowieka. Kraków, Oficyna Wydawnicza IMPULS, 2007. p. 135-147.
21. Schwartz KL, Crossley-May H, Vigneau FD, Brown K, Banerjee M. Race, socioeconomic status and stage at diagnosis for five common malignancies. Cancer Causes Control. 2003; 14(8):761-766.

22. Wardle J, Steptoe A. Socioeconomic differences in attitudes and beliefs about healthy lifestyles. J Epidemiol Community Health. 2003; 57(6):440-3.

23. Peek ME, Sayaa JV, Markwardt R. Fear, fatalism and breast cancer screening in low income African-American women: The role of clinicians and the health care system. J Gen Intern Med. 2008; 23(11):1847-53.

24. Niederdeppe J, Levy AG. Fatalistic beliefs about cancer prevention and tree prevention behaviors. Cancer Epidemiol Biomarkers Prev. 2007; 16: 998-1003.

25. Ochrona zdrowia w gospodarstwach domowych w $2006 \mathrm{r}$. Warszawa, GUS Departament Badań Społecznych, 2006.

26. Corner J. et al. Experience of health changes and reasons for delay in seeking care: a UK study of the months prior to the diagnosis of lung cancer. Soc Sci Med. 2006; 62: 1381-1391. 